\title{
Electrical Water Bath Stunning of Broilers: Effects on Breast Meat Quality
}

\author{
Cassiana Kissel $^{1}$, Adriana L. Soares ${ }^{1}$, Alexandre $\mathrm{Oba}^{2}$ and Massami Shimokomaki ${ }^{1,2,3}$ \\ ${ }^{1}$ Graduate Program in Food Science, Department of Food Science and Technology, Londrina State University, \\ POB 6001, CEP 86051-980, Londrina, PR, Brazil. Brazil \\ ${ }^{2}$ Graduate Program in Animal Science, Department of Animal Science, Londrina State University, \\ POB 6001, CEP 86051-980, Londrina, PR, Brazil. Brazil \\ ${ }^{3}$ Paraná Federal Technological University, Londrina Campus, Londrina, PR, Brazil
}

\begin{abstract}
The objective of this study was to investigate the influence of electrical water bath stunning treatments (pulsed direct current) on stress conditions of poultry meat. This was carried out by evaluating meat quality measured through the incidence of PSE (pale, soft, exudative) in broiler breast fillet meat. We applied the randomized factorial design $2^{2}$ with three replications at the central point, with independent variables, including voltage $(40,80,120 \mathrm{~V})$ and electrical frequency $(100,400,700 \mathrm{~Hz})$. The response functions under study were $\mathrm{pH}, \mathrm{L}^{*}, \mathrm{a}^{*}, \mathrm{~b}^{*}, \mathrm{WHC}$ and incidence of PSE meat. Samples presenting with $\mathrm{pH}$ of $\leq 5.80$ and $\mathrm{L}^{*}$ of $\geq 53.0$ were classified as PSE whereas those with $5.80<\mathrm{pH}<6.00$ and $44.0<\mathrm{L}^{*}<53.0$ were considered normal. The fillets taken from birds without stunning presented $54.14 \%$ of PSE meat samples, which decreased to $25.0 \%$ with stunning. The response functions $\mathrm{L}^{*}$ and incidence of PSE showed regression $(P \leq 0.05)$ with good adjustment of experimental data to the proposed model. The lowest incidence of PSE meat was observed when voltage and frequency were at their highest levels. In poultry slaughter, the applied electric stunning voltage of $120 \mathrm{~V}$ with a frequency of $700 \mathrm{~Hz}$ was determined to be the most effective for inhibition of PSE development.
\end{abstract}

Key words: frequency, PSE broiler chicken meat, voltage

J. Poult. Sci., 52: 74-80, 2015

\section{Introduction}

In most countries, stunning of animals for slaughter is a legal requirement, where the animals for meat consumption should instantaneously be rendered insensible and remain insensitive to pain until the brain is completely unresponsive (Council Directive 93/119/ CEE, 1993). The most universally accepted means to immobilize birds before slaughter is electrical stunning (Bilgili, 1999). The state of unconsciousness induced by electricity results from the inhibition of impulses in both the reticular activating and the somatosensory systems (Heath et al., 1994). The electrical current reaching the brain should be adequate enough to induce a seizure and render the bird to be insensitive to pain (Gregory and Wotton, 1989). In general, this current is less than that required for ventricular fibrillation; thus, avoiding killing by electrocution. However, while insufficient current may physically immobilize the bird, it cannot prevent its per-

Received: August 22, 2013, Accepted: May 17, 2014

Released Online Advance Publication: June 25, 2014

Correspondence: A.L. Soares, State University of Londrina, Agricultural Sciences Center - Department of Food Science and Technology, POB 6001, Londrina, Parana, Brazil, CEP 86051-980, Brazil.

(E-mail: adri.soares@uel.br) ception of pain, stress, or discomfort (Fletcher, 1993). The intensity of electric current used for stunning can vary among poultry slaughterhouses. Those in the European Community recommend that the minimum current used for stunning to be $120 \mathrm{~mA}$, which will induce cardiac arrest in $90 \%$ of the birds. This causes instantaneous and irreversible stunning (Poole and Fletcher, 1998), which ensures that the birds are not subjected to any conscious stress associated with recovery from the stunning. In the United States, the voltage and frequency used in the chicken stunning vary, with $77.4 \%$ of poultry slaughterhouse systems utilizing low voltage systems $(10$ to $25 \mathrm{~V})$ with high frequency $(500 \mathrm{~Hz})$ (Gregory and Wotton, 1989). In these cases, the main objective of stunning is immobilization of the bird with minimal carcass damage (Heath et al., 1994). In Brazil, the electrical current or the voltage applied varies among slaughterhouses, and there is currently no legal specification. This current causes generalized contractions that can have an obvious and marked effect on muscle characteristics. For example, if excessive currents or low frequencies are used, the electrical stunning has the potential to induce bleeding and broken bones as a result of strong contractions (Gregory and Wilkins, 1989; Rawles et al., 1995). These stressful conditions accelerate the onset of rigor mortis, which would be 
avoided by the use of proper use of electrical stunning methodologies (Ma and Adis, 1973; Papinaho and Fletcher, 1995). Contreras and Beraquet (2001) studied the effect of various voltages $(20,40,80$ and $100 \mathrm{~V}$ at $60 \mathrm{~Hz}$ and no stunning) and frequencies $(60,200,350,500$ and $1000 \mathrm{~Hz}$ at $40 \mathrm{~V}$ ) on the efficiency of stunning, blood loss and defects in chicken carcass. At a current of $40 \mathrm{~V}$ and frequency of 1000 $\mathrm{Hz}$, they observed that $90 \%$ of animals were stunned and blood loss was maximized. Furthermore, additional studies demonstrated that stressful conditions just before preslaughter activities promoted the development of PSE (pale, soft, exudative) meat (Mitchell and Kettlewell, 1998; Barbut et al., 2008; Oba et al., 2009). This was shown to be caused by the rapid decline of $\mathrm{pH}$ values while the carcass is still warm; thus, leading to the denaturation of myofibrillar proteins (Olivo et al., 2001, Barbut, 1997) and loss of their functional properties (Kissel et al., 2009).

Several studies have examined the relationship between electrical stunning and animal stress with emphasis on meat quality (Lee et al., 1979; Craig and Fletcher, 1997; Northcutt et al., 1998; Bilgili, 1999; Alvarado and Sams, 2000; Gregory, 2005) however thus far, this has not been established. Thus, the objective of the present study was to investigate the influence of electrical stunning on the animal's stress and the subsequent effect on meat quality.

\section{Material and Methods}

\section{Animals}

The experiment was conducted during the summer season in a commercial slaughterhouse in the southwest region of the state of Mato Grosso, Brazil. The Cobb mixed-sex broilers, aged 44 days were routinely prepared for slaughter after a 6-h fast prior to harvesting. The birds were manually harvested with 8-10 animals per cage, and received an overall shower mist before truck transportation (Simões et al., 2009, Langer et al., 2010). During transportation, the average speed was $60 \mathrm{~km} / \mathrm{h}$ and the distance from the farm to the commercial slaughterhouse was $40 \mathrm{~km}$. During truck reception at the slaughterhouse, the birds received an ambient temperature $\left(30.5^{\circ} \mathrm{C} \pm 2\right)$ water mist and ventilation for 40 min before slaughter.

\section{Animal Slaughter and Sample Collection}

Before slaughter, birds were divided into 2 groups: The first group was under the treatment of water shower mist and electrical stunning (WtS) $(n=30)$ and the other without stunning $(\mathrm{WoS})(n=30)$. The electrical stunning was performed with a stunner machine (FX 3.0 CC, Industrial Electronic Flux) under pulsed direct current, with the chicken's head submerged in a vat with clean water. The electrical parameters were as follows: voltage $=80 \mathrm{~V}$ and frequency $=$ $400 \mathrm{~Hz}$ for $14 \mathrm{~s}$ per bird. The automated bleed was performed within $2 \mathrm{~s}$ of stunning. The WoS birds were hung and immediately bled manually, which took approximately 5 min. Subsequently, the activities followed the standard industrial practices consisting essentially of scalding at $58^{\circ} \mathrm{C}$ for $2 \mathrm{~min}$, defeathering, mechanical evisceration, and cooling, first in a pre-chiller ( 8 to $16^{\circ} \mathrm{C}$ for $12 \mathrm{~min}$ ) followed by a chiller $\left(0\right.$ to $4^{\circ} \mathrm{C}$ for $50 \mathrm{~min}$ ), after which the carcasses were moved forward using a cold-water counter flow design. The breast fillet samples (Pectoralis major) were collected approximately $1 \mathrm{~h}$ and $30 \mathrm{~min}$ after death and stored at $4^{\circ} \mathrm{C}$ for $24 \mathrm{~h}$ prior to the analysis of $\mathrm{pH}$, color ( $\mathrm{L}^{*}, \mathrm{a}^{*}$ and $\left.\mathrm{b}^{*}\right)$, and water holding capacity (WHC).

\section{Experimental Design}

We used a $2^{2}$ full factorial experimental design with three replicates at the center point, where the independent variables were: voltage and electrical frequency, levels $-1,0$ and +1 , for a total of 7 assays (Table 1). The assays were conducted randomly and each assay used 30 chickens. The response surface methodology (RSM) was used to evaluate the effects of voltage $\left(\mathrm{x}_{1}\right)$ and frequency $\left(\mathrm{x}_{2}\right)$ and their interaction on the dependent variables or responses. The response functions evaluated were: $\mathrm{pH}, \mathrm{L}^{*}$, PSE percentage and water holding capacity. The analysis of variance (ANOVA) and the coefficients of determination $\left(\mathrm{R}^{2}\right)$ were used to compare the fit of the models against the experimental data. The repetitions at the central point provided the degrees of freedom to calculate the pure error and, subsequently, the lack of fit test. All analyses were carried out and all graphs were created using the STATISTICA program for Windows, version 7.0 (Statsoft, 2004). The model for each response was expressed in the form of Equation 1, where $\hat{\mathrm{Y}}=$ response, $\mathrm{x}_{1}$ and $\mathrm{x}_{2}=$ codified variables voltage and frequency, respectively, and $\beta=$ estimated coefficient on the response surface, and $\mathrm{e}=$ pure error.

$$
\hat{\mathrm{Y}}=\beta_{0}+\beta_{1} \mathrm{x}_{1}+\beta_{2} \mathrm{x}_{2}+\beta \mathrm{x}_{1} \mathrm{x}_{2}+\mathrm{e}
$$

(Equation 1)

To compare the results between the WtS and WoS treatments we used the Student's $t$-test at $5 \%$ probability (STATISTICA 7.0 software, Statsoft, 2004). For the incidence of PSE measurement, we used the binary variation (1 and 0 ) where 1 means normal and 0 means PSE meat.

\section{pH and Color Measurement}

The $\mathrm{pH}$ values were determined by inserting electrodes into the breast muscle using a contact $\mathrm{pH}$ meter system (Testo, Model 205). The analysis was performed in triplicate

Table 1. Experimental assay for the $\mathbf{2}^{\mathbf{2}}$ full factorial design with three replications at the center point (C)

\begin{tabular}{ccc}
\hline \hline & \multicolumn{2}{c}{ Independent Variables } \\
Assay & Voltage & Frequency \\
& $\mathrm{x}_{1}\left(\mathrm{X}_{1}\right)$ & $\mathrm{x}_{2}\left(\mathrm{X}_{2}\right)$ \\
\hline 1 & $-1(40 \mathrm{~V})$ & $-1(100 \mathrm{~Hz})$ \\
2 & $+1(120 \mathrm{~V})$ & $-1(100 \mathrm{~Hz})$ \\
3 & $-1(40 \mathrm{~V})$ & $+1(700 \mathrm{~Hz})$ \\
4 & $+1(120 \mathrm{~V})$ & $+1(700 \mathrm{~Hz})$ \\
$5(\mathrm{C})$ & $0(80 \mathrm{~V})$ & $0(400 \mathrm{~Hz})$ \\
$6(\mathrm{C})$ & $0(80 \mathrm{~V})$ & $0(400 \mathrm{~Hz})$ \\
$7(\mathrm{C})$ & $0(80 \mathrm{~V})$ & $0(400 \mathrm{~Hz})$ \\
\hline
\end{tabular}

$\mathrm{x}_{\mathrm{i}}$-Encoded value; $\mathrm{X}_{\mathrm{i}}-$ real value 
$24 \mathrm{~h}$ post-mortem as previously described by Olivo et al. (2001).

A colorimeter (Minolta CR 400) was used to evaluate the color parameters on the posterior surface of the fillets, including $\mathrm{L}^{*}$ (lightness), a* (red component), and $\mathrm{b}^{*}$ (yellow component), with three different reading points at the sample surface (Soares et al., 2002).

\section{Classification of Chicken Fillets}

The samples were classified as either PSE or normal meats based on $\mathrm{pH}$ and $\mathrm{L}^{*}$ values as described by Soares et al. (2002). Thus, the fillets with $\mathrm{L}^{*}{ }_{24 \mathrm{~h}} \geq 53.0$ and $\mathrm{pH}_{24 \mathrm{~h}} \leq 5.80$ values were classified as PSE, while samples under $44.0<$ $\mathrm{L}^{*}{ }_{24 \mathrm{~h}}<53.0$ and $5.80<\mathrm{pH}_{24 \mathrm{~h}}<6.00$ values were considered normal.

\section{Water Holding Capacity (WHC) Measurement}

WHC was determined based on the technique described by Hamm (1960). Samples weighing $2.00 \pm 0.10 \mathrm{~g}$ were carefully placed between two filter papers and left under a $10 \mathrm{~kg}$ weight for $5 \mathrm{~min}$. The samples were weighed again and the WHC was calculated and expressed as a percentage of water exuded using the formula: WHC $(\%)=100-[($ initial weight - final weight) / (initial weight)] (Wilhelm et al., 2010).

\section{Results and Discussion}

Table 2 shows the average values of $\mathrm{pH}$, color $\left(\mathrm{L}^{*}, \mathrm{a}^{*}\right.$ and $\left.\mathrm{b}^{*}\right)$, WHC, and PSE incidence of chicken fillets from birds subjected to $\mathrm{WtS}$ [conditions $=80 \mathrm{~V}, 400 \mathrm{~Hz}$ (ES)] and those from WoS conditions. Compared to WoS samples, WtS samples showed post-mortem $\mathrm{pH}$ values that were significantly higher $(P \leq 0.05), 5.87$ compared to 5.82 , respectively. These results are consistent with a previous study (Craig and Fletcher, 1997), which observed that fillets from WtS broilers under high current $(125 \mathrm{~mA}, 50 \mathrm{~Hz}, 5 \mathrm{~s})$ or low voltage $(11 \mathrm{~V}, 500 \mathrm{~Hz}, 10 \mathrm{~s})$ showed higher $\mathrm{pH}$ values than those from non-stunned birds. The lower $\mathrm{pH}$ value observed for fillets from WoS birds was directly related to stress experienced at the time of bleeding, which promotes an increased rate of glycolysis in muscles. The application of electrical stunning has been associated with a decreased rate of post-mortem glycolysis. This is due to lower stress re-

Table 2. Values of $\mathbf{p H}$ and color $\left(\mathrm{L}^{*}, \mathbf{a}^{*}, \mathbf{b}^{*}\right)$, water holding capacity (WHC) and the PSE incidence in broiler fillets with (WtS, $80 \mathrm{~V}$ and $400 \mathrm{~Hz}$ ) and without stunning (WoS)

\begin{tabular}{lrr}
\hline \hline & \multicolumn{1}{c}{ WtS } & \multicolumn{1}{c}{ WoS } \\
\hline $\mathrm{pH}_{24 \mathrm{~h}}$ & $5.87^{\mathrm{a}} \pm 0.08$ & $5.82^{\mathrm{b}} \pm 0.09$ \\
$\mathrm{~L}^{*}{ }_{24 \mathrm{~h}}$ & $52.53^{\mathrm{b}} \pm 1.80$ & $54.91^{\mathrm{a}} \pm 2.42$ \\
$\mathrm{a}^{*}{ }_{24 \mathrm{~h}}$ & $3.15^{\mathrm{b}} \pm 0.75$ & $4.50^{\mathrm{a}} \pm 0.57$ \\
$\mathrm{~b}^{*}{ }_{24 \mathrm{~h}}$ & $5.04^{\mathrm{a}} \pm 1.20$ & $5.01^{\mathrm{a}} \pm 1.07$ \\
$\mathrm{WHC}_{24 \mathrm{~h}}$ & $65.45^{\mathrm{a}} \pm 2.28$ & $63.99^{\mathrm{a}} \pm 4.84$ \\
PSE Incidence $^{1}$ & $0.75^{\mathrm{a}}$ & $0.43^{\mathrm{b}}$ \\
\hline
\end{tabular}

${ }^{\mathrm{a}, \mathrm{b}}$ Means followed by different letters in the same row differ by the Student's t-test at $5 \%$ probability $(p \leq 0.05)$.

${ }^{1}$ Mean of binary variation, where: 1 - Normal and 0 - PSE. sulting from birds showing less fighting movements at the time of sacrifice (Lee et al., 1979; Thomson et al., 1986; Murphy et al., 1988). The $\mathrm{pH}$ response obtained experimentally $(\mathrm{Y})$ and the estimated model $(\hat{\mathrm{Y}})$ are shown in Table 3, while Table 4 presents the analysis of variance for models generated for the response functions.

The chicken fillets from slaughtered WoS birds showed L* values significantly higher (54.91) than those from WtS birds (52.53) (Table 2). Alvarado and Sams (2000) observed higher $\mathrm{L}^{*}$ values for turkey filets that were slaughtered under WoS conditions comparing to turkey meat samples from WtS. Furthermore, Craig et al. (1999) also found that fillets samples from WtS $(11 \mathrm{~V}, 500 \mathrm{~Hz}$ for $10 \mathrm{~s}$ and $125 \mathrm{~mA}, 60 \mathrm{~Hz}$ for $5 \mathrm{~s}$ ) had lower $\mathrm{L}^{*}$ values when compared to the control group of WoS. The results of our $\mathrm{pH}$ and $\mathrm{L}^{*}$ determination studies on fillet samples from WoS birds indicate that these animals suffered profound stress at the time of sacrifice as measured by the incidence of PSE meat.

Fillets of slaughtered chickens from the WoS group had a* values (Table 2) significantly higher samples from the filets of broilers slaughtered under WtS conditions, showing more reddish coloration. These results are consistent with the study of Takahashi et al. (2009), which found that fillets from chickens slaughtered without stunning were redder (higher $a^{*}$ value) than fillets from electrically-stunned chickens $(40$ and $90 \mathrm{~V} / 800 \mathrm{~Hz}$ ).

It is possible that the reddish coloration of fillets from WoS chicken was the result of the incomplete removal of blood from the muscle at slaughter. In fact, less blood loss was observed in carcasses from WoS chickens in relation to WtS under at $20,40,80$, and $100 \mathrm{~V}$ with a frequency of 60 $\mathrm{Hz}$ and also varying the frequency of $60,200,350,500$ and $1000 \mathrm{~Hz}$ at a constant voltage of $40 \mathrm{~V}$ (Contreras and Beraquet, 2001). In contrast, stunning the animal by any method produces a rise in blood pressure in the arteries, capillaries, and veins and causing a transient increase in heart rate, which are all factors that favor successful bleeding (Thornton, 1969).

In contrast to the $L^{*}$ and $a^{*}$ values, $b^{*}$ values did not differ $(P>0.05)$ between treatment groups (Table 2). Our results were similar to those reported by others who have evaluated different stunning methods, including: electrical $(13 \mathrm{~Hz}$ and $500 \mathrm{~mA}$ for $7 \mathrm{~s})$, gas $\left(70 \%\right.$ Argon and $\left.30 \% \mathrm{CO}_{2}\right)$, and no electrical stunning (Alvarado et al., 2007); in addition to electrical stunning with low voltage $(11 \mathrm{~V}, 500 \mathrm{~Hz}$ for $10 \mathrm{~s})$ and high current $(125 \mathrm{~mA}, 60 \mathrm{~Hz}$ for $5 \mathrm{~s})$ and no electrical stunning (Craig et al., 1999).

In relation to the WHC values, they were not significantly different between treatment groups (Table 2), although the chicken fillets from $\mathrm{WtS}$ birds presented lower $\mathrm{pH}$ and higher $\mathrm{L}^{*}$ values. Takahashi et al. (2009) found that fillets from WoS chickens presented lower WHC values in comparison to fillet samples from WtS chickens under high and low voltage ( $40 \mathrm{~V}$ and $90 \mathrm{~V} /$ high frequency for both $800 \mathrm{~Hz}$ ).

The incidence of PSE fillets was evaluated according to the variation binary ( 1 and 0 ), where 1 means normal and 0 means PSE. These values differed significantly among the 
Table 3. $\mathbf{2}^{\mathbf{2}}$ full factorial with the independent variables (voltage and frequency) and the experimental response functions $(Y)$ and estimated $(\hat{Y})$ model for the evaluation of electrical stunning on broiler chicken meat quality

\begin{tabular}{|c|c|c|c|c|c|c|c|c|c|c|c|c|c|c|}
\hline \multirow{4}{*}{ Assay } & \multicolumn{14}{|c|}{ Independent variables } \\
\hline & \multirow{3}{*}{$\begin{array}{l}\text { Voltage } \\
\mathrm{x}_{1}\left(\mathrm{X}_{1}\right)\end{array}$} & \multirow{3}{*}{$\begin{array}{l}\text { Frequency } \\
\qquad \mathrm{x}_{2}\left(\mathrm{X}_{2}\right)\end{array}$} & \multirow{2}{*}{\multicolumn{2}{|c|}{$\mathrm{pH}$}} & \multirow{2}{*}{\multicolumn{2}{|c|}{$\mathrm{L}^{*}$}} & \multirow{2}{*}{\multicolumn{2}{|c|}{ Color }} & \multirow{2}{*}{\multicolumn{2}{|c|}{$\mathrm{b}^{*}$}} & \multirow{2}{*}{\multicolumn{2}{|c|}{$\mathrm{WHC}^{1}(\%)$}} & \multirow{2}{*}{\multicolumn{2}{|c|}{$\begin{array}{c}\text { PSE Incidence } \\
(\%)\end{array}$}} \\
\hline & & & & & & & & & & & & & & \\
\hline & & & $\mathrm{Y}$ & $\hat{\mathrm{Y}}$ & $\mathrm{Y}$ & $\hat{\mathrm{Y}}$ & $\mathrm{Y}$ & $\hat{\mathrm{Y}}$ & $\mathrm{Y}$ & $\hat{Y}$ & $\mathrm{Y}$ & $\hat{\mathrm{Y}}$ & $\mathrm{Y}$ & $\hat{\mathrm{Y}}$ \\
\hline 1 & $\begin{array}{c}-1 \\
(40 \mathrm{~V})\end{array}$ & $\begin{array}{c}-1 \\
(100 \mathrm{~Hz})\end{array}$ & $\begin{array}{c}5.80 \\
\pm 0.13\end{array}$ & 5.80 & $\begin{array}{l}53.28 \\
\pm 2.11\end{array}$ & 53.38 & $\begin{array}{c}3.80 \\
\pm 0.86\end{array}$ & 3.57 & $\begin{array}{c}5.47 \\
\pm 1.64\end{array}$ & 5.33 & $\begin{array}{l}65.19 \\
\pm 2.68\end{array}$ & 65.46 & 56.67 & 59.17 \\
\hline 2 & $\begin{array}{c}+1 \\
(120 \mathrm{~V})\end{array}$ & $\begin{array}{c}-1 \\
(100 \mathrm{~Hz})\end{array}$ & $\begin{array}{c}5.85 \\
\pm 0.11\end{array}$ & 5.84 & $\begin{array}{l}53.44 \\
\pm 2.09\end{array}$ & 53.54 & $\begin{array}{c}3.91 \\
\pm 0.71\end{array}$ & 3.67 & $\begin{array}{c}4.35 \\
\pm 1.16\end{array}$ & 4.22 & $\begin{array}{l}66.99 \\
\pm 6.45\end{array}$ & 67.27 & 43.33 & 45.83 \\
\hline 3 & $\begin{array}{c}-1 \\
(40 \mathrm{~V})\end{array}$ & $\begin{array}{c}+1 \\
(700 \mathrm{~Hz})\end{array}$ & $\begin{array}{c}5.75 \\
\pm 0.13\end{array}$ & 5.74 & $\begin{array}{l}55.79 \\
\pm 2.80\end{array}$ & 55.79 & $\begin{array}{c}3.83 \\
\pm 1.11\end{array}$ & 3.59 & $\begin{array}{c}5.73 \\
\pm 1.08\end{array}$ & 5.59 & $\begin{array}{l}61.11 \\
\pm 3.12\end{array}$ & 61.38 & 70 & 72.50 \\
\hline 4 & $\begin{array}{c}+1 \\
(120 \mathrm{~V})\end{array}$ & $\begin{array}{c}+1 \\
(700 \mathrm{~Hz})\end{array}$ & $\begin{array}{c}5.88 \\
\pm 0.11\end{array}$ & 5.88 & $\begin{array}{l}52.75 \\
\pm 2.08\end{array}$ & 52.86 & $\begin{array}{c}3.95 \\
\pm 0.94\end{array}$ & 3.71 & $\begin{array}{c}5.82 \\
\pm 1.24\end{array}$ & 5.69 & $\begin{array}{l}64.01 \\
\pm 3.61\end{array}$ & 64.28 & 20 & 22.50 \\
\hline 5 & $\begin{array}{c}0 \\
(80 \mathrm{~V})\end{array}$ & $\begin{array}{c}0 \\
(400 \mathrm{~Hz})\end{array}$ & $\begin{array}{c}5.78 \\
\pm 0.11\end{array}$ & 5.81 & $\begin{array}{l}54.34 \\
\pm 2.02\end{array}$ & 53.92 & $\begin{array}{l}3.56 \\
\pm 1.05\end{array}$ & 3.64 & $\begin{array}{c}4.20 \\
\pm 0.98\end{array}$ & 5.21 & $\begin{array}{l}65.82 \\
\pm 2.54\end{array}$ & 64.60 & 56.67 & 50 \\
\hline 6 & $\begin{array}{c}0 \\
(80 \mathrm{~V})\end{array}$ & $\begin{array}{c}0 \\
(400 \mathrm{~Hz})\end{array}$ & $\begin{array}{c}5.78 \\
\pm 0.12\end{array}$ & 5.81 & $\begin{array}{l}54.12 \\
\pm 2.33\end{array}$ & 53.92 & $\begin{array}{c}3.66 \\
\pm 0.92\end{array}$ & 3.64 & $\begin{array}{c}5.49 \\
\pm 1.11\end{array}$ & 5.21 & $\begin{array}{l}65.10 \\
\pm 2.40\end{array}$ & 64.60 & 53.33 & 50 \\
\hline 7 & $\begin{array}{c}0 \\
(80 \mathrm{~V})\end{array}$ & $\begin{array}{c}0 \\
(400 \mathrm{~Hz})\end{array}$ & $\begin{array}{c}5.85 \\
\pm 0.09\end{array}$ & 5.81 & $\begin{array}{l}53.72 \\
\pm 2.19\end{array}$ & 53.92 & $\begin{array}{c}2.77 \\
\pm 0.74\end{array}$ & 3.64 & $\begin{array}{c}5.39 \\
\pm 1.02\end{array}$ & 5.21 & $\begin{array}{l}63.98 \\
\pm 2.82\end{array}$ & 64.60 & 50 & 50 \\
\hline
\end{tabular}

$\mathrm{x}_{\mathrm{i}}$ : Coded Value; $\mathrm{X}_{\mathrm{i}}$ : Real Value; ${ }^{1}$ WHC: Water Holding Capacity; ${ }^{2}$ SF: Shear Force.

Table 4. Analysis of variance for response functions $\mathbf{p H}, \mathrm{L}^{*}, \mathbf{a}^{*}, \mathbf{b}^{*}, \mathrm{WHC}$ and PSE incidence of broiler fillets

\begin{tabular}{lccccccc}
\hline \hline \multicolumn{1}{c}{ Response } & DF & SS & MS & F & p & $\mathrm{R}^{2}$ & P of Lack of fit \\
\hline $\mathrm{pH}$ & 6 & 0.01 & 0.004 & 2.16 & 0.44 & 0.74 & 0.0005 \\
$\mathrm{~L}^{*}$ & 6 & 5.47 & 1.82 & 18.69 & 0.06 & 0.95 & 0.1 \\
$\mathrm{a}^{*}$ & 6 & 0.013 & 0.004 & 0.018 & 0.93 & 0.01 & 0.50 \\
$\mathrm{~b}^{*}$ & 6 & 0.46 & 0.15 & 0.885 & 0.46 & 0.53 & 0.17 \\
WHC & 6 & 18.33 & 6.11 & 7.12 & 0.27 & 0.88 & 0.71 \\
PSE Incidence & 6 & $1,363.98$ & 454.66 & 40.88 & 0.10 & 0.94 & 58.33 \\
\hline
\end{tabular}

$\mathrm{DF}=$ degree of freedom, $\mathrm{SS}=$ sum of square, $\mathrm{MS}=$ mean square

slaughtered chicken fillets from the WtS and WoS treatment groups (Table 2). The lowest mean was observed for the WoS treatment, indicating a higher incidence of PSE. The occurrence of PSE in chicken fillets from WtS and WoS birds is shown in Fig. 1. For slaughtered WtS chickens (80 $\mathrm{V}$ and $400 \mathrm{~Hz}$ ), we observed that the incidence of PSE was $25 \%$, which was much lower than those from WoS birds (57.14\%).

The ANOVA for the models generated is presented in Table 4. The response functions $\mathrm{pH}, \mathrm{a}^{*}, \mathrm{~b}^{*}$, and WHC presented a nonsignificant regression, indicating that the model inadequately fits the experimental data (Table 4). It is likely that the $\mathrm{pH}$ response function was not significant due to the small variation observed for this response of 5.75 (Assay 3) to 5.88 (Assay 4) (Table 3). Other reports also have demonstrated that different electrical stunning systems did not affect meat $\mathrm{pH} 24 \mathrm{~h}$ post-mortem (Thomson et al., 1986; Papinaho and Fletcher, 1995; Papinaho et al., 1995). The response function $a^{*}$ varied from 2.77 (Assay 7) to 3.95
(Assay 4) (Table 3), while the response function $b^{*}$ ranged from 4.20 (Assay 5) to 5.82 (Assay 4). The WHC showed a variation of $61.11 \%$ (Assay 3 ) to $66.99 \%$ (Assay 2), which is supported by previous data in a study by Craig et al. (1999). This study found no significant differences in the loss of water for cooking stunned chicken breast fillets under high current $(125 \mathrm{~mA}, 60 \mathrm{~Hz}, 5 \mathrm{~s})$ or low voltage $(11 \mathrm{~V}, 500 \mathrm{~Hz}$, $10 \mathrm{~s})$.

For response function $\mathrm{L}^{*}$, it was observed that assay 4 $(120 \mathrm{~V}, 700 \mathrm{~Hz})$ resulted in the lowest value $(52.75)$, while assay $3(40 \mathrm{~V}, 700 \mathrm{~Hz})$ presented the highest value (55.79), indicating a higher influence of stress in birds treated with lower voltage. An analysis of variance of this response function (Table 4) showed that the regression was significant and the lack of fit was not significant. The overall coefficient of determination $\left(\mathrm{R}^{2}\right)$ was 0.9481 , indicating that $94.81 \%$ of the variation was explained by the model, meaning the experimental data fit the model well. Equation 2 shows the proposed model for the effect of variables codified voltage 
$\left(\mathrm{x}_{1}\right)$ and frequency $\left(\mathrm{x}_{2}\right)$ on the lightness of the fillets.

$$
\mathrm{L}^{*}=53.92-0.72 * \mathrm{x}_{1}+0.46 \mathrm{x}_{2}-0.8 * \mathrm{x}_{1} \mathrm{x}_{2}
$$

where: $\mathrm{L}^{*}=$ lightness, $\mathrm{x}_{1}=$ Voltage $(\mathrm{V}) ; \mathrm{x}_{2}=$ Frequency $(\mathrm{Hz})$, *Significant $(P \leq 0.05)$

It was observed that the effect of voltage $\left(\mathrm{x}_{1}\right)$ was significant and negative, indicating that the increased tension caused a decrease in the $L^{*}$ value. The response surface (Fig. 2) showed that lower $L^{*}$ values were observed when the voltage and frequency were used at higher levels (i.e., $120 \mathrm{~V}$ and $700 \mathrm{~Hz}$ ). In contrast, higher L* values were ob-

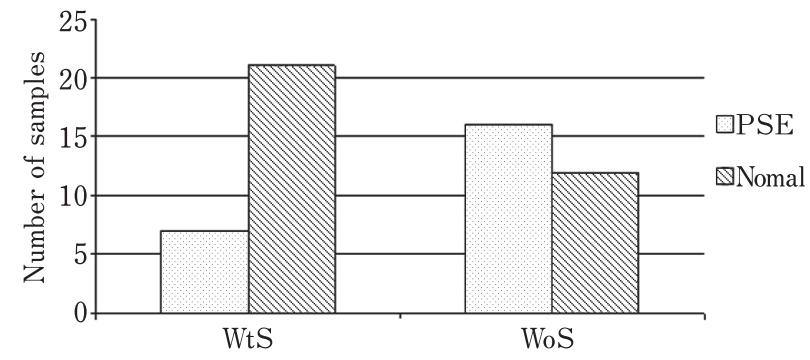

Fig. 1. Occurrence of PSE vs. normal meat in breast fillets from WtS and WoS broiler chickens. served with the lower voltage $(40 \mathrm{~V})$ and higher frequency $(700 \mathrm{~Hz})$, indicating that these conditions lead to a lower quality of chicken meat.

In relation the response function PSE incidence, it was observed that assay $4(120 \mathrm{~V}, 700 \mathrm{~Hz})$ demonstrated the lowest incidence $(20 \%)$, while the assay $3(40 \mathrm{~V}, 700 \mathrm{~Hz})$ presented the highest $(70 \%)$ (Table 3$)$. The tests with the lowest level of the variable voltage $(40 \mathrm{~V})$ had the highest incidence of PSE, regardless of the level of applied frequency (assays 1 and 3, with $56.67 \%$ and $70 \%$, respectively). The analysis of variance of this response function was significant and lack of fit was not significant (Table 4). The overall coefficient of determination $\left(\mathrm{R}^{2}\right)$ was 0.9442 , indicating that the model explained $94.42 \%$ of the variation (which means a good fit of the model to experimental data). Equation 3 shows the proposed model for the effect of variables codified voltage $\left(\mathrm{x}_{1}\right)$ and frequency $\left(\mathrm{x}_{2}\right)$ on the PSE incidence.

$$
\begin{array}{r}
\text { PSE Incidence }=50-15.84 * \mathrm{x}_{1}-2.5 \mathrm{x}_{2}-9.17 * \mathrm{x}_{1} \mathrm{x}_{2} \\
\text { Equation (3) }
\end{array}
$$

where: $\mathrm{x}_{1}=$ Voltage $(\mathrm{V}) ; \mathrm{x}_{2}=$ Frequency $(\mathrm{Hz}) ;{ }^{*}$ Significant $(P \leq 0.05)$.

We observed that the effect of voltage $\left(\mathrm{x}_{1}\right)$ was significant and negative, indicating that the increased voltage caused a reduction in the incidence of chicken PSE fillets. Furthermore, the interaction between voltage and frequency was
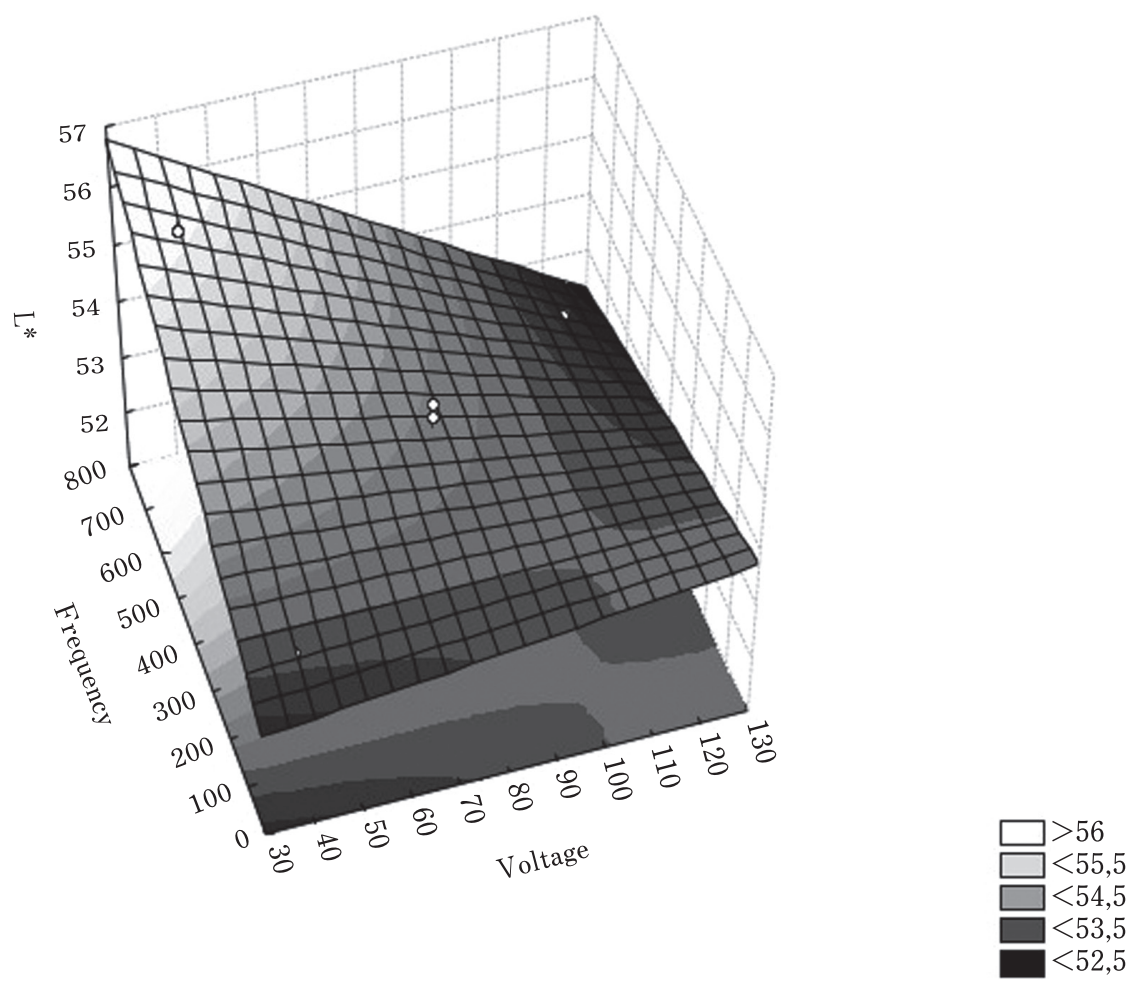

Fig. 2. Response surface of voltage $\left(x_{1}\right)$ and frequency $\left(x_{2}\right)$ effect applied in electrical stunning on the lightness $\left(\mathrm{L}^{*}\right)$ of broiler chicken fillet meat. 


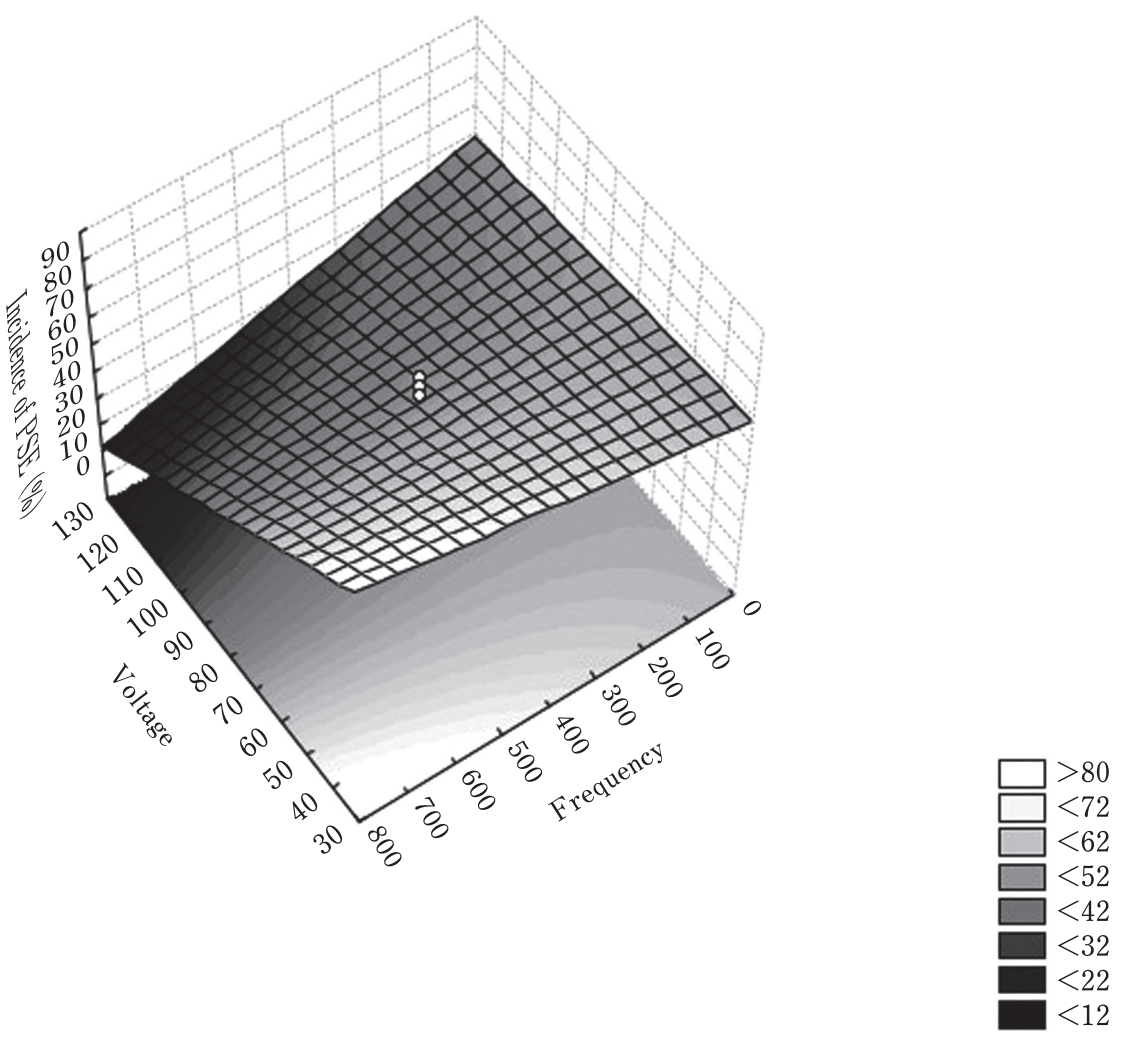

Fig. 3. Response surface of the effect of voltage $\left(x_{1}\right)$ and frequency $\left(x_{2}\right)$ applied in electrical stunning on the incidence of broiler chicken PSE meat.

negative and significant. The response surface (Fig. 2) showed that the lowest incidence of PSE was in the range of both higher electrical voltage and frequency, suggesting that when broiler chickens were stunned at $120 \mathrm{~V}$ and $700 \mathrm{~Hz}$, they suffered less stress, thus resulting in better meat quality.

In conclusion, the application conditions of electric stunning under voltage of $120 \mathrm{~V}$ and frequency of $700 \mathrm{~Hz}$ before bleeding resulted in best quality of breast fillet meat.

\section{Acknowledgments}

CK present address: Federal Institute of Education, Science and Technology of Mato Grosso, Campo Novo do Parecis Campus, Campo Novo do Parecis, MT, Brazil. The authors acknowledge with thanks the financial support of PRONEX n ${ }^{\circ} 17.347$ from CNPq/Fundação Araucária. MS is a CNPq Research Fellow.

\section{References}

Alvarado CZ and Sams AR. Rigor mortis development in turkey breast muscle and the effect of electrical stunning. Poultry Science, 79: 1694-1698. 2000.

Alvarado CZ, Richards MP, O'Keefe SF and Wang H. The Effect of blood removal on oxidation and shelf life of broiler breast meat. Poultry Science, 86: 156-161. 2007.

Barbut, S. Problem of pale, soft and exudative meat in broiler chickens. British Poultry Science, 38: 74-77, 1997.

Barbut S, Sosnicki AA, Lonergan SM, Knapp T, Ciobanu DC, Gatcliffe LJ, Huff-Lonergan E and Wilson EW. Progress in reducing the pale, soft and exudative (PSE) problem in pork and poultry meat. Meat Science, 79: 46-63. 2008.

Bilgili SF. Recent advances in electrical stunning. Poultry Science, 78: 282-286, 1999.

Contreras CC and Beraquet NJ. Electrical stunning, hot boning, and quality of chicken breast meat. Poultry Science, 80: 501-507. 2001.

Council Directive (93/119/CEE) of 22 December 1993 on the protection of animals at the time of slaughter or killing.

Craig EW and Fletcher DL. A comparison of high current and low voltage electrical stunning systems on broiler breast rigor development and meat quality. Poultry Science, 76: 11781181. 1997.

Craig EW, Fletcher DL and Papinaho, PA. The effects of antemortem electrical stunning and postmortem electrical stimulation on biochemical and textural properties of broiler breast meat. Poultry Science, 78: 490-494. 1999.

Fletcher DL. Stunning of broilers. Broiler Industry, 56: 40-46. 1993.

Gregory NG and Wilkins LJ. Effect of stunning current on carcass quality in chickens. Veterinary Record, 124: 530-532. 1989.

Gregory NG and Wotton SB. Effect of electrical stunning on somatosensory evoked potentials in chickens. British Veterinary Journal, 145: 159-164. 1989. 
Gregory NG. Recent concerns about stunning and slaughter. Meat Science, 70: 481-491. 2005.

Hamm R. Biochemistry of meat hydratation. Advances of Food Research. 10: 335-443. 1960.

Heath GE, Thaler AM and James WO. A survey of stunning methods currently used during slaughter of poultry in commercial poultry plants. Journal of Applied Poultry Research, 3: 297302. 1994.

Kissel C, Soares AL, Rossa A and Shimokomaki M. Functional properties of PSE (pale, solf, exudative) broiler meat in the production of Mortadella. Brazilian Archives of Biology and Technology, 52: 213-217. 2009.

Langer ROS, Simões GS, Soares AL, Oba A, Rossa A, Shimokomaki M and Ida EI. Broiler transportation conditions in a Brazilian commercial line and the occurrence of breast PSE (pale, soft, exudative) meat and DFD-like (dark, firm, dry) meat. Brazilian Archives of Biology and Technology, 53: 1161-1167. 2010.

Lee YB, Hargus JL, Webb JE, Rickansrud DA and Hagberg EC. Effect of electrical stunning on postmortem biological changes and tenderness in broiler breast muscle. Journal of Food Science, 44: 1121-1128. 1979.

Ma RTI and Addis PB. The association of struggle during exsanguination to glycolysis, protein solubility, and shear in turkey pectoralis muscle. Journal of Food Science, 38: 995-997. 1973.

Mitchell MA and Kettlewell PJ. Physiological stress and welfare of broiler chickens in transit: solutions not problem! Poultry Science, 77: 1803-1814. 1998.

Murphy BS, Hasiak RJ and Sebranek JG. Effect of antemortem electrical stunning on functional properties of turkey muscle. Poultry Science, 67: 1062-1068. 1988.

Northcutt JK, Buhr RJ and Young LL. Influence of preslaughter stunning on turkey breast muscle quality. Poultry Science, 77: 487-492. 1998.

Oba A, Almeida M, Pinheiro JW, Ida EI, Marchi DF, Soares AL and Shimokomaki M. The effect of management of transport and lairage conditions on broiler chicken breast meat quality and DOA (death on arrival). Brazilian Archives of Biology and Technology, 52: 205-211. 2009.

Olivo R, Soares AL, Ida EI and Shimokomaki M. Dietary vitamin E inhibits poultry PSE and improves meat function properties.
Journal of Food Biochemistry, 25: 271-283. 2001.

Papinaho PA and Fletcher DL. Effect of stunning amperage on broiler breast muscle rigor development and meat quality. Poultry Science, 74: 1527-1532. 1995.

Papinaho PA, Fletcher DL and Buhr RJ. Effect of electrical stunning amperage and peri-mortem struggle on broiler breast rigor development and meat quality. Poultry Science, 74: 15331539. 1995.

Poole GH and Fletcher DL. Comparison of a modified atmosphere stunning-killing system to conventional electrical stunning and killing on selected broiler breast muscle rigor development and meat quality attributes. Poultry Science, 77: 342-347. 1998.

Rawles D, Marcy J and Hulet M. Constant current stunning of market weight broilers. Journal of Applied Poultry Research, 4: 109-116. 1995.

Simões GS, Oba A, Matsuo T, Rossa A, Shimokomaki M and Ida EI. Vehicle thermal microclimate evaluation during Brazilian summer broiler transport and the occurrence of PSE (pale, soft, exudative) meat. Brazilian Archives of Biology and Technology, 52: 195-204. 2009.

Soares AL, Lara JAF, Ida EI, Guarnieri PD, Olivo $\mathrm{R}$ and Shimokomaki M. Variation in the colour of Brazilian broiler breast fillet. Proceedings of International Congress of Meat Science and Technology, 48: 540-541. 2002.

Statsoft, Inc. (2004). STATISTICA (data analysis software system), version 7. www.statsoft.com.

Takahashi SE, Mendes AA, Komiyama CM, Souza HBA, Paz ICLA, Garcia RG, Moreira J, Balog Neto A and Boiago M. Efeito do atordoamento elétrico e tipo de desossa sobre a ocorrência de carne pálida em frangos de corte. Veterinary y Zootecnia, 3: 61-69. 2009.

Thomson JE, Lyon CE, Hamm D, Dickens JA, Fletcher DL and Shackelford AD. Effects of electrical stunning and hot deboning on broiler breast meat quality. Poultry Science, 65: 17151719. 1986.

Thornton H. Compêndio de inspeção de carnes. Londres: Bailliere Tindall an Cassel. 1969.

Wilhelm AE, Magaghini MB, Hernández-Blazquez FJ, Ida EI and Shimokomaki M. Protease activity and the ultrastructure of broiler chicken PSE (pale, soft, exudative) meat. Food Chemistry, 119: 1201-1204. 2010. 